The final version of this paper was published by Edward Elgar in the Queen Mary Journal of Intellectual Property (2014) Volume 4(3), p226-235.

\title{
5 Pointz Down: The New York District Court Ruling on 'Graffiti Mecca'.
}

\author{
Jonathan Cohen et al v G\&M Realty LP et al, Case No 13-CV-5612 (FB) (JMA) (EDNY 2013)
}

\section{Introduction:}

The perception of Graffiti both in the aesthetic and wider cultural sense has modified considerably over recent times. In an era when Banksy is the doyen of much of the popular media and critical circles, it is perhaps timely that the legal system reflects on this evolving artform and questions traditional assumptions on which the interpretation of the law is premised.

The 5 Pointz building in Long Island City, Queens, New York has come to be known as many things in recent years including 'Graffiti Mecca', 'The United Nations of Graffiti' and 'The Institute of Higher Burnin'. By 2013, the two hundred thousand square foot former factory had become the foremost global setting for the public exhibition of graffiti and a major New York tourist attraction. From the early to mid-1990's onwards the 5 Pointz, then known as the 'Phun Phactory', had become the site for a disorganised array of what the court deemed 'distasteful graffiti' ${ }^{1}$ by aerosol artists. In an attempt to control this situation, Jonathan Cohen, a graffiti artist known in the art world as 'Meres One', approached the property's owner, Jerry Wolkoff, with a proposition that he would curate the works at 5 Pointz. This proposition was accepted by Wolkoff, who stated that he "was supportive of creative efforts but wanted somebody to manage it." ${ }^{2}$ This was not a written agreement but rather a 'general agreement that [Cohen] would be allowed to select who would be permitted to paint on the walls. ${ }^{3}$

In 2013, on receipt of the news that the building was due for demolition and redevelopment, the artists concerned sought an injunction in the District Court under the moral rights provisions of the Visual Artists Rights Act 1990 (VARA) ${ }^{4}$ which offers protection to authors of visual works of art in relation to the intentional distortion, mutilation, or other modification of that work which would be prejudicial to his or her honor or reputation, and any intentional distortion, mutilation, or modification of that work is a violation of that right' ${ }^{5}$ and which also seeks 'to prevent any destruction of a work of recognized stature, and any intentional or grossly negligent destruction of that work is a violation of that right. ${ }^{6}$ Both of these sections are subject to limitations as set out in 17 USC $\S 113(\mathrm{~d})^{7}$. It was under the latter provision that this action proceeded.

\footnotetext{
${ }^{1}$ Jonathan Cohen et al $v$ G\&M Realty LP et al, Case No 13-CV-5612 (FB) (JMA) (EDNY 2013) 10

${ }^{2}$ Jonathan Cohen et al v G\&M Realty LP et al, Case No 13-CV-5612 (FB) (JMA) (EDNY 2013) 10

${ }^{3}$ Jonathan Cohen et al $v$ G\&M Realty LP et al, Case No 13-CV-5612 (FB) (JMA) (EDNY 2013) 10

4 17USC $\$ 106 \mathrm{~A}$

${ }^{5} 17 \mathrm{USC} \S 106 \mathrm{~A}(\mathrm{a})(3)(\mathrm{A})$

${ }^{6}$ 17USC $\$ 106 \mathrm{~A}(\mathrm{a})(3)(\mathrm{B})$

${ }^{7}$ These include, inter alia, provisions requiring the owner to give the requisite notice to the artist if that owner is proceeding with the destruction of the property.
} 
The final version of this paper was published by Edward Elgar in the Queen Mary Journal of Intellectual Property (2014) Volume 4(3), p226-235.

Judge Frederic Block expressly acknowledged, this case is the first in which a court in the US has had to adjudicate on whether works of exterior graffiti art, given their inherent transient nature, are worthy of legal protection.

\section{Graffiti and the Law.}

Traditional assumptions about graffiti are generally premised on the presumption that such works are illegal, accordingly the Oxford English Dictionary definition is thus, "Writing or drawings scribbled, scratched, or sprayed illicitly on a wall or other surface in a public place'. ${ }^{8}$ But as an art form graffiti has evolved from an indicator of urban decline to become a widely accepted and acknowledge form of artistic self-expression. ${ }^{9}$ The vocabulary in the discourse around such art has migrated from that related to gang's territorial marking and acts of vandalism to that of the masterpiece, the recent sale of Banksy's work 'Kissing Coppers' for over half a million dollars again confirming this new found status. ${ }^{10}$ It is also now the case that much contemporary graffiti, as in the case at hand, is painted legally.

Legal graffiti has been held copyrightable in the $\mathrm{US}^{11}$ once it satisfies the criteria of being an original work of authorship that is fixed in 'a tangible medium of expression. ${ }^{12}$ Copyright Law has often been professed to remain content neutral at least in terms of express restrictions but it is arguable that the strength of this assertion has varied at any given time. The New York District Court has previously held that works are not eligible for copyright protection if a work is not original or 'free from illegality to immorality ${ }^{13}$ but more recent decisions have held illegal works may be eligible for protection. ${ }^{14}$ The current position could safely be described as uncertain. It is a fact however that 'the assertion that illegal graffiti is barred from copyright protection is an untested one, as no court has held directly on the legality requirement vis-a-vis graffiti art. ${ }^{15}$ In the instant case however there was general agreement that the graffiti in question was created with permission.

VARA's moral rights provisions have been held to apply only to legal graffiti. ${ }^{16}$ Under VARA a work of visual art is defined as 'a painting, drawing, print, or sculpture, existing in a single copy, in a limited edition of 200 copies' but as not including 'any poster, map, globe, chart, technical drawing, diagram, model, applied art, motion picture or other audiovisual work...' ${ }^{17}$ As stated, for the

\footnotetext{
${ }^{8}$ Oxford English Dictionary (3 ${ }^{\text {rd }}$ ed, Oxford University Press, 2010)

${ }^{9}$ http://america.aljazeera.com/watch/shows/consider-this/Consider-This-blog/2013/10/15/how-hasgraffitievolved.html accessed on 08/03/2014

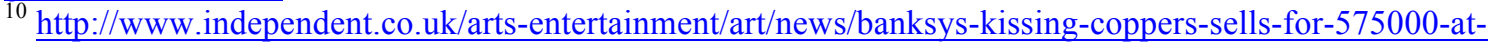
miami-street-art-auction-9138032.html accessed on 08/03/2014

${ }^{11}$ Murray Hill Publ'ns, Inc v ABC Commc'ns, Inc, 264 F.3d 622 (6th Cir 2001); Mager v Brand New Sch, 78 USPQ 2d 1389 (SDNY 2004)

1217 USC $\$ 102(\mathrm{a})$

${ }^{13}$ Hoffman v Le Traunik, 209 F 375, 379 (NDNY 1913) ; Bullard v Esper, 72 F Supp548 (ND Tex 1947)

${ }^{14}$ See eg: Mitchell Bros Film Grp v Cinema Adult Theatre, $604 \mathrm{~F} 2 \mathrm{~d} 852$ ( $5^{\text {th }}$ Cir 1979); FlavaWorks, Inc $v$ Gunter, 689 F.3d 754, 755 (7th Cir 2012)

15 Al Roundtree, Graffiti Artists 'Get Up' in Intellectual Property's Negative Space (2012-2013) 31 Cardozo Arts \& Ent LJ 959, 969

${ }^{16}$ English $v$ BFC \& R E $11^{\text {th }}$ St LLC, 1997 WL 746444 (SDNY). This case related to a community garden developed without permission. The judgment relied on the decision of a Californian court, Botello $v$ Shell Oil Co, 280 Cal Rptr 535 (Ct App 1991) where it was held that state moral rights provision applied only to legally created artworks, the court stating, 'It obviously does not apply to graffiti, which... is hardly classifiable as "fine art", (and) which is the subject of several criminal laws.'

1717 USC $\$ 101$
} 
The final version of this paper was published by Edward Elgar in the Queen Mary Journal of Intellectual Property (2014) Volume 4(3), p226-235.

purposes of moral rights relating to destruction, the work must be of a 'recognized stature', it is this aspect of the statute that occupied the court most during the hearing for injunctive relief.

\section{The Decision:}

The plaintiffs sought a preliminary injunction under the provisions a 17 USC $\S 106 \mathrm{~A}(\mathrm{a})(3)(\mathrm{b})$ of VARA, the moral rights provisions protecting the integrity of an artwork, which allow for protection against the destruction of the work in certain circumstances. The plaintiff's further sought to argue that their prospective contractual relations had been tortuously interfered with by the defendants and also that Jonathan Cohen has an easement in gross to use the buildings but these latter arguments were dismissed as meritless. On November 12, 2013, the application for injunction was refused and a written opinion on the matter was delivered on November 20, 2013. On the November 19, 2013, the plaintiffs' counsel filed a letter with the court to confirm that 'under the cover of darkness' the previous night all the visual art at 5 Pointz had been whitewashed over by the defendants. ${ }^{18}$ The primary issues that the District Court focused on were those of whether the works in question were of the necessary 'recognised stature' to engage the relevant VARA moral rights provisions and secondly, whether the inherent transient nature of the graffiti at hand would mitigate against the granting of injunctive relief.

\section{Recognised Stature:}

The plaintiffs adduced 24 photographs of works that had been present on the walls of 5 Pointz which they argued were of the requisite 'recognised stature'. VARA does not define 'recognised stature' and the District court sought to delineate the boundaries of the term by first referencing both the District ${ }^{19}$ and Second Circuit decisions in Carter $v$ Helmsley-Spear Inc. ${ }^{20}$ Interestingly, rather than view the aforementioned VARA protection against the destruction of works of 'recognised stature' as a subset of the integrity right, the Second Circuit saw this protection as conceptually a separate right from the general integrity right. ${ }^{21}$ The district court decision in Carter provided a two tier test for the determination of the stature of a work. Firstly, '(1) that the visual art in question has 'stature' i.e. is viewed meritorious, and (2) that this stature is 'recognised' by art experts, other members of the artistic community, or by some cross-section of society. ${ }^{, 2}$ Carter aside, Judge Block found only three other cases that had broached the substantive issue of what constituted 'recognised stature', one circuit court and two from the district court.

The Seventh Circuit in Martin v City of Indianapolis ${ }^{23}$ commented that 'the Carter v Helmsley Spear test may be more rigorous that Congress intended.' In Pollara $v$ Seymour ${ }^{24}$ the district court that a

\footnotetext{
${ }_{18}$ Jonathan Cohen et al v G\&M Realty LP et al, Case No 13-CV-5612 (FB) (JMA) (EDNY 2013) 2

${ }^{19}$ Carter v Helmsley-Spear Inc, $71 \mathrm{~F} 3 \mathrm{~d} 77$

${ }^{20}$ Carter v Helmsley-Spear Inc, 861 F Supp 303 (SDNY 1994)

${ }^{21}$ Carter v Helmsley-Spear Inc, 71 F 3d 77, 83

${ }^{22}$ Carter v Helmsley-Spear Inc, 861 F Supp 303, 325 (SDNY 1994). The District court also interestingly note at this point that an earlier draft of VARA contained provisions that allowed a court to 'take into account the opinion of artists, art dealers, collectors of fine art, and other persons involved with the creation, appreciation, history, or marketing of works of recognised sources.' It also stated that a court could 'can, and should, consider these sources.'

${ }^{23}$ Martin v City of Indianapolis, 192 F 3d 608, 612 (7th Cir 1999)

${ }^{24}$ Pollara v Seymour, 206 F Supp 2d 333 (NDNY 2002)
} 
work was not of recognised stature because while it was 'unquestionably meritorious' it was 'intended solely as a display piece for a one-time event. ${ }^{25}$ The court further stated that 'it defies the underlying purpose of VARA to assume that the statute was intended to protect works of artistic merit without regard to whether such works were ever intended to be preserved for posterity as works of artistic merit. ${ }^{26}$ Lastly, in Scott $v$ Dixon a statue housed in a secluded back garden was not deemed to attract protection as 'while the Sculpture may have artistic merit, it was not a work of recognised stature within the meaning of VARA', this as a result of the fact that it had not been exposed to the public. ${ }^{27}$

Much of the testimony in relation to the 24 selected 5 Pointz works did not differentiate between the two 'discreet words' but did on the whole equate artistic merit with 'recognised stature. ${ }^{28}$ One of the plaintiffs, Danielle Mastrion, stated that her work 'Kool Herc' (one of the 24 works presented by the plaintiffs) was of recognised stature as it satisfied criteria such as 'technical ability, composition, color, line work, detail and also the artist's credentials' ${ }^{29}$ However the testimony of art experts from both sides in the case did focus on the issue of public recognition the works.

Professor Erin Thompson for the defence stated that while quality is undoubtedly a factor in stature, that more correctly 'stature is recognizing not particular qualities of objects, but the way these objects are valued by the public. ${ }^{30}$ She further stated that while innovation and uniqueness in a work should be of a threshold where scholars agree that the work is 'changing the history of art', she testified that none of the works in question met this standard. ${ }^{31}$ The fact that 5 Pointz had achieved a wide recognition as a tourist attraction did not in in itself satisfy VARA according to Thompson, unless visitor's came to see 'a particular work of art ${ }^{32}$ She did however cite Banksy as proof that aerosol art could attain the standard of 'recognised stature', citing, inter alia, the myriad dissertations and scholarly articles referencing his work as evidence of this. ${ }^{33}$ Lastly, Thompson did acknowledge that 'something can be ephemeral and achieve recognised stature. ${ }^{, 34}$

For the plaintiffs, Daniel Simmons, head of the Rush Philanthropic arts Foundation and owner of two New York art galleries, testified that all 24 works in question qualified as 'real artworks'. ${ }^{35} \mathrm{He}$ focused on the inherent qualities of the art, its 'design, color, shape, form' and characteristics of 'symmetry' and 'innovation'. ${ }^{36}$ Of Danielle Mastrion's 'Kool Herc', he stated that 'there's enough people that know what [the work] looks like, and feels like and what it's trying to impart; that it would be, to me, if it was missing from the canon of art history, that it would be a loss. ${ }^{, 37}$ In terms of exposure to the public, Simmons characterised the building in question as 'the '5Pointz Museum of Street Art' and consequently argued that such a justifiable characterisation and the number of visitors coming to the site makes any work on the building of recognised stature. He cited Meres One's 'Drunken Bulbs' as an example of a 5 Pointz work that is iconic and also that people do come

${ }^{25}$ Pollara v Seymour, 206 F Supp 2d 333, 336 (NDNY 2002)

${ }^{26}$ Pollara v Seymour, 206 F Supp 2d 333, 336 (NDNY 2002)

${ }^{27}$ Scott v Dixon, 309 F Sup. 2d 395, 406 (EDNY 2004)

${ }^{28}$ Jonathan Cohen et al v G\&M Realty LP et al, Case No 13-CV-5612 (FB) (JMA) (EDNY 2013) 13

${ }^{29}$ Jonathan Cohen et al v G\&M Realty LP et al, Case No 13-CV-5612 (FB) (JMA) (EDNY 2013) 13

${ }^{30}$ Jonathan Cohen et al v G\&M Realty LP et al, Case No 13-CV-5612 (FB) (JMA) (EDNY 2013) 14

31 Jonathan Cohen et al v G\&M Realty LP et al, Case No 13-CV-5612 (FB) (JMA) (EDNY 2013) 14

${ }^{32}$ Jonathan Cohen et al $v$ G\&M Realty LP et al, Case No 13-CV-5612 (FB) (JMA) (EDNY 2013) 15

${ }^{33}$ Jonathan Cohen et al $v$ G\&M Realty LP et al, Case No 13-CV-5612 (FB) (JMA) (EDNY 2013) 16

${ }^{34}$ Jonathan Cohen et al v G\&M Realty LP et al, Case No 13-CV-5612 (FB) (JMA) (EDNY 2013) 16

${ }^{35}$ Jonathan Cohen et al v G\&M Realty LP et al, Case No 13-CV-5612 (FB) (JMA) (EDNY 2013) 16

${ }^{36}$ Jonathan Cohen et al $v$ G\&M Realty LP et al, Case No 13-CV-5612 (FB) (JMA) (EDNY 2013) 16

${ }^{37}$ Jonathan Cohen et al v G\&M Realty LP et al, Case No 13-CV-5612 (FB) (JMA) (EDNY 2013) 17 
The final version of this paper was published by Edward Elgar in the Queen Mary Journal of Intellectual Property (2014) Volume 4(3), p226-235.

specifically to see this piece on the basis of this and the artists reputation. ${ }^{38}$ Simmons likened this work (and another by Lady Pink) to a Picasso that had just been 'brought up from the basement' making the work 'instantly famous because of the stature of the artist.' ${ }^{39}$ In summation he stated that if the artworks in question were lost that:

'I think New York City as a whole would be diminished. It's a major tourist attraction for long Island City. It is part of the development of Long Island City. Just like, pretty much ... MoMa being there, it's a drawing point for artists and art lovers to come from all over the world to see. ${ }^{40}$

\section{Works Duration:}

The court heard that Jerry Wolkoff had been emphatic, when he and Cohen made their 2002 agreement, stating that he was ultimately 'going to be knocking the building down' and the arrangement 'was always temporary'. ${ }^{41}$ Cohen on the other hand testified there had been no discussion of life span but acknowledged that he did have fear for the longevity of the arrangement. ${ }^{42}$ Cohen stated that there was a hierarchy of works at 5Pointz, on certain walls the art was temporary and quickly rotating and could last from a day to a week, other works however were deemed to be 'permanent', meaning they would last as long as he and the current set up was there, the artist being the only one with the authority to remove it. ${ }^{43}$ At the time the injunction was sought 5 Pointz housed about 350 images, 100 of them Cohen's. Evidence was also produced of a 2011 video interview with Cohen where he acknowledged the transient nature of the works in question. ${ }^{44}$ It was also noted by the court that Mastrion's 'Kool Herc' was painted in July 2013 and that the artist was aware both of the general fact that the building could come down and at any time, and more specifically was aware that the owners were actively seeking approval for demolition approval at the time she created the work. ${ }^{45}$

\section{Refusal of Injunctive Relief:}

Judge Block cited Picasso's statement that 'the purpose of art is washing the dust of daily life off our souls' and speculated that such an artist would have wishes VARA protection for contemporary aerosol art. ${ }^{46}$ But he continued that VARA only protects works of art and does not grant the authority to preserve tourist sites. ${ }^{47} \mathrm{He}$ did however acknowledge that at least some of the works in question presented 'sufficiently serious questions going to the merits to make them fair grounds for litigation' but held that the trial rather than the preliminary injunction stage was more a more appropriate setting for determining the issue of whether the works were of recognised stature. ${ }^{48}$

\footnotetext{
${ }^{38}$ Jonathan Cohen et al $v$ G\&M Realty LP et al, Case No 13-CV-5612 (FB) (JMA) (EDNY 2013) 18

${ }^{39}$ Jonathan Cohen et al $v$ G\&M Realty LP et al, Case No 13-CV-5612 (FB) (JMA) (EDNY 2013) 18

${ }^{40}$ Jonathan Cohen et al $v$ G\&M Realty LP et al, Case No 13-CV-5612 (FB) (JMA) (EDNY 2013) 19-20

${ }^{41}$ Jonathan Cohen et al $v$ G\&M Realty LP et al, Case No 13-CV-5612 (FB) (JMA) (EDNY 2013) 19

${ }^{42}$ Jonathan Cohen et al $v$ G\&M Realty LP et al, Case No 13-CV-5612 (FB) (JMA) (EDNY 2013) 19

${ }^{43}$ Jonathan Cohen et al $v$ G\&M Realty LP et al, Case No 13-CV-5612 (FB) (JMA) (EDNY 2013) 20

44 Jonathan Cohen et al $v$ G\&M Realty LP et al, Case No 13-CV-5612 (FB) (JMA) (EDNY 2013) 21

45 Jonathan Cohen et al $v$ G\&M Realty LP et al, Case No 13-CV-5612 (FB) (JMA) (EDNY 2013) 22

46 Jonathan Cohen et al v G\&M Realty LP et al, Case No 13-CV-5612 (FB) (JMA) (EDNY 2013) 23

47 Jonathan Cohen et al $v$ G\&M Realty LP et al, Case No 13-CV-5612 (FB) (JMA) (EDNY 2013) 23

${ }^{48}$ Jonathan Cohen et al $v$ G\&M Realty LP et al, Case No 13-CV-5612 (FB) (JMA) (EDNY 2013) 24
} 
In determining whether the plaintiffs had suffered irreparable harm and were therefore entitled to an injunction the court stated that:

'[a]lthough the works have now been destroyed - and the Court wished it had the power to preserve them -the plaintiffs would be hard pressed to contend that no amount of money would compensate them for their paintings; and VARA -which makes no distinction between temporary and permanent works of visual art- provides significant monetary damages may be awarded for their wrongful destruction. ${ }^{49}$

The court emphasised the difference between the 5 Pointz art works and more traditional ones that are more readily marketable, but did stress the fact that the plaintiffs' works can live on through other media through which they may enjoy copyright protection. $^{50}$

In the context of examining the issues of irreparable harm and the balance of hardships, the determinate factor in the court's failure to grant an injunction was 'the transient nature of the plaintiffs' work. ${ }^{51}$ The court stated that Cohen always knew the building would be coming down also placed importance on the fact that many painting were recently created while the plaintiffs knew that the City Planning Commission had approved the defendant's redevelopments plans. In this sense the court stated, 'In a very real sense, (the) plaintiffs' have created their own hardships. ${ }^{52}$

The court stated that the defendants do bear some of the responsibility given the fact that gave the project their blessing but did not seek VARA waivers. ${ }^{53}$ It was also noted that the defendants stood to benefit economically from the attention that the site had attracted in terms of marketing his new premises. ${ }^{54}$ Judge Block reiterated that VARA protects temporary works from destruction and as a result the 'defendants are exposed to potentially significant monetary damages if it is ultimately determined after trial that the plaintiffs' works were of 'recognised stature. ${ }^{, 55}$

In terms of the public interest, the court stated that the City Planning Commission was requiring that 3,300 square feet of the new development on the site was to be made available for art. ${ }^{56}$ It was stated that should more space be given toward this end and if Cohen was allowed to continue in his curatorial role that the court may find such gestures persuasive when and if the issue of financial damages is to be addressed and that such moves may lead to a reincarnation for 5 Pointz. ${ }^{57}$ Injunctive relief in this case was not given on the basis of the transient nature of the works but yet VARA does give protection to temporary works, as a result damages may be accruing to plaintiffs. It remains to be seen if the case proceeds on that basis.

\footnotetext{
49 Jonathan Cohen et al $v$ G\&M Realty LP et al, Case No 13-CV-5612 (FB) (JMA) (EDNY 2013) 25

${ }^{50}$ Jonathan Cohen et al $v$ G\&M Realty LP et al, Case No 13-CV-5612 (FB) (JMA) (EDNY 2013) 25-26

51 Jonathan Cohen et al $v$ G\&M Realty LP et al, Case No 13-CV-5612 (FB) (JMA) (EDNY 2013) 26

52 Jonathan Cohen et al $v$ G\&M Realty LP et al, Case No 13-CV-5612 (FB) (JMA) (EDNY 2013) 26

53 Jonathan Cohen et al $v$ G\&M Realty LP et al, Case No 13-CV-5612 (FB) (JMA) (EDNY 2013) 26

${ }^{54}$ Jonathan Cohen et al $v$ G\&M Realty LP et al, Case No 13-CV-5612 (FB) (JMA) (EDNY 2013) 26

${ }_{55}^{5}$ Jonathan Cohen et al $v$ G\&M Realty LP et al, Case No 13-CV-5612 (FB) (JMA) (EDNY 2013) 26-27

${ }^{56}$ Jonathan Cohen et al v G\&M Realty LP et al, Case No 13-CV-5612 (FB) (JMA) (EDNY 2013) 27

57 Jonathan Cohen et al $v$ G\&M Realty LP et al, Case No 13-CV-5612 (FB) (JMA) (EDNY 2013) 27
} 
The final version of this paper was published by Edward Elgar in the Queen Mary Journal of Intellectual Property (2014) Volume 4(3), p226-235.

\section{Conclusions:}

It is true that one could argue that this judgment does not address perhaps some of the wider and more interesting questions that suggest themselves in the area of graffiti and intellectual property law. For example, the aforementioned issues related to illegality and also the interaction between the originality requirement and graffiti were not dealt with. On the latter point, would simpler works containing painted single words be deemed in many cases to fulfil the 'modicum of creativity" ${ }^{58}$ that is now the US threshold for originality? It must also be borne in mind that typefaces are not protectable per se under US copyright law. ${ }^{59}$ That having been said, the case does raise a number of pertinent issues concerning the evolving phenomenon of graffiti and how the law struggles to accommodate it. The case is all the more valuable in this regard given the paucity of judgments in this area, this due perhaps to the fact that the underlying nature and purpose of much graffiti is constructed around a "core value of rebellion. ${ }^{60}$ Such artists seeing themselves as beyond mainstream culture and particularly the legal system, hence the thought of seeking legal remedy is culturally alien.

In terms of the issues this case does confront, perhaps the most central is the criteria (or arguably lack thereof) for determining what is 'recognised stature' and the inherent broad subjective nature of the designation of same. VARA draws a distinction between mutilation and destruction of a work in an attempt to balance competing property rights and those moral interests of the artist. In the context of mutilation, an artist must demonstrate damage to honour or reputation but with destruction the work must be of 'recognised stature'. ${ }^{61}$ There is consistent tension in jurisprudence between merit free assessments in identifying projectable subject matter and the inherent and often unavoidable need to resort to exactly such criteria to solve ontological aesthetic quandaries and resultant legal taxonomic quandaries. ${ }^{62}$ It may nonetheless be the case that some legislative guidance on the factors that are determinative for what constitutes recognised stature would indeed be warranted. ${ }^{63}$ The use of language such as 'preserved for posterity', as per the Pollara ${ }^{64}$ judgment is unhelpful in the extreme when dealing with many contemporary forms of artistic expression in this context.

On the issue of the section 113(d) provisions, which require notification to be furnished to the artist in a situation of impending destruction, it is arguable that these measures do not go far enough. ${ }^{65}$ This section refers to 90 days' notice that needs to be given to the artist pre-destruction of the work but this

\footnotetext{
${ }^{58}$ Feist Publications, Inc v Rural Telephone Service Co, 499 US 340 (1991)

${ }^{59}$ Eltra Corp v Ringer, 579 F 2d 294 (4 ${ }^{\text {th }}$ Cir 1978). While typefaces are not in themselves subject of copyright protection, instructions as to their form contained in a computer program were held to be copyrightable in Adobe Sys Inc v Southern Software Inc, 45 USPQ 2d 1827 (ND Cal 1998), thereby gaining them effective indirect protection against verbatim copying at least. This explains the bizarre wording of Copyright Office Regulation 202.1 (e) which states that 'typeface as typeface' is not protectable.

${ }^{60}$ Al Roundtree, Graffiti Artists 'Get Up' in Intellectual Property's Negative Space (2012-2013) 31 Cardozo Arts \& Ent LJ 959, 966

${ }^{61}$ The latter provision is also broader in the sense that it allows for recovery for grossly negligent as well as intentional acts.

${ }^{62}$ For an example of this under UK law see Metix v Maughan [1997] FSR 718, 719. Here in an attempt to clarify the definition of sculpture Laddie $J$ held that an artist is one who considers themselves and is considered by others as such. Thereby arguably opening up the subjective options of 'others' to indirectly inform the definition of sculpture.

${ }^{63}$ David Yates and Courtney Fiddian, 'Now you see me: protecting visual art' (2014) 27(1) Australian Intellectual Property law Bulletin 9, 12

${ }^{64}$ Pollara v Seymour, 206 F Supp 2d 333, 336 (NDNY 2002)

${ }^{65}$ William Brutocao and Eric Bjorgum, 'VARA and CAPA: Lessons from the Twitchell Case' (Intellectual Property Today September 2008) < http://www.iptoday.com/articles/2008-9-brutocao.asp > accessed $13 / 03 / 2014$
} 
The final version of this paper was published by Edward Elgar in the Queen Mary Journal of Intellectual Property (2014) Volume 4(3), p226-235.

apparently only applies if the owner of the building had intended the artwork be removed or destroyed. This wording thereby potentially leaves a gap in protection for artists in relation to situations where a contractor acts on their own volition unknown to the owner. ${ }^{66}$ In this case it is factually unclear as to the circumstances but nevertheless it would seem reasonable to aver that this loop hole needs to be addressed in order to achieve a better balance of owners and artist's rights and also to allow prospective plaintiff's to apply for injunctive relief where this semantic lacuna may ultimately prevent them doing. ${ }^{67}$

As noted above, VARA does indeed protect transient works but the questions remain as to the degree of transience permissible under the Act. The spectrum of case law in relation to fixation leaves a distinct lack of clarity. The Seventh $7^{\text {th }}$ Circuit in Kelley $v$ Chicago Park District ${ }^{68}$ held that an artist's wildflower garden was 'inherently changeable, not fixed' while in the regularly cited, and indeed criticised, decision of MAI Systems Corp v Peak Computers, even random access memory (RAM) copies of a work have been held to satisfy the fixation requirement by the Ninth Circuit. ${ }^{69}$ There has previously been a view expressed that 'the proliferation of computer games may cause other courts to liberalize the fixation requirement', ${ }^{70}$ but whether this will ultimately inform judgments concerning fixation decision in the artistic arena remains to be seen but it is without doubt that more clarification in this area is currently warranted.

The developing position of legal graffiti is undoubtedly highlighted by this case. When thinking of museums and galleries in the context of more traditional art, sites such as 5Pointz and the phenomenon known as free walls (areas provided for by city authorities or other property owners as a designated area for legal graffiti where the property owner retains some control over content) have come to act as a highly contextualised equivalent exhibitory forum for graffiti. ${ }^{71}$ The level of transience in works may fluctuate on a case by case basis, but examples such as the 5 Pointz which contain the added aspect of curatorship, do indicate that fixation may not be always necessarily at issue or at least to the extent previously thought.

The 'recognised stature' requirement indicates both a realignment (when compared with the honor and reputation threshold required in relation to mutilation) of the weighting of respective rights between the artist and the building owner but also is indicative of a 'preservative' cultural function in term of public policy. ${ }^{72}$ The District Court makes further reference to the concerns of Congress in terms of 'significant societal loss' if such works are destroyed. ${ }^{73}$ At this point one may ask whether it is appropriate that it is left to the artist to protect such a cultural societal resource through their moral rights? But further discussion of this point is beyond the scope of this comment. The loss of 5Pointz may be characterised as such a loss despite the references in submissions and Judges Block's summation to it as a mere 'tourist site', a phrase which arguable belittles the cultural significance of

\footnotetext{
${ }^{66}$ William Brutocao and Eric Bjorgum, 'VARA and CAPA: Lessons from the Twitchell Case' (Intellectual Property Today September 2008) < http:/www.iptoday.com/articles/2008-9-brutocao.asp > accessed $13 / 03 / 2014$

${ }^{67}$ David Yates and Courtney Fiddian, 'Now you see me: protecting visual art' (2014) 27(1) Australian Intellectual Property law Bulletin 9, 11

${ }^{68}$ Kelley $v$ Chicago Park District 635 F.3d 290, 304 ( $7^{\text {th }}$ Cir 2011)

69991 F2d 518 (9 $9^{\text {th }}$ Cir 1993)

${ }^{70}$ Joan Infarinato, 'Copyright Protection for Short Lived Works of Art' (1982-83) 51 Fordham L Rev 90,113

${ }^{71}$ Other jurisdictions are engaging with these changing realities. In 2009 the Brazilian government for example passed law 706/07 which decriminalised street art where it was done with the building owners consent.

${ }^{72}$ Carter v Helmsley-Spear Inc, 861 F Supp 303, 324 (SDNY 1994)

${ }^{73}$ Carter v Helmsley-Spear Inc, 861 F Supp 303, 324 (SDNY 1994)
} 
The final version of this paper was published by Edward Elgar in the Queen Mary Journal of Intellectual Property (2014) Volume 4(3), p226-235.

the location. Yet in fairness to the Judge, one would have to acknowledge that the court in its closing comments in relation to the mitigating steps that the owners may take in relation to damages contain an implicit recognition of the 'societal loss' that has occurred.

Notwithstanding the fact that the issue of monetary damages in case still outstanding, the 5 Pointz example does demonstrate that, while inherent equities will always play a factor in determinations at both injunctive relief stage and at trial in actions such as this, the conception of what constitutes a work of 'recognised stature' may need clarification and subtle re-alignment to reflect the growing position of graffiti within both the cannon of visuals arts and in terms of its position as cultural property. ${ }^{74}$ This District Courts decision also highlights that resolution is needed around the issue of how transient art indeed may be and yet still qualify for VARA protection. It also in time, depending on the damages awarded, may come to demonstrate whether or not the application of VARA does provide a practical working deterrent to the destruction of some culturally significant legal graffiti.

\footnotetext{
${ }^{74}$ On this latter point see the UK example of Banksy and Haringey Council; Ben Quinn, 'Haringey council: Banksy mural belongs in our community (Guardian 19/02/2013) $<$ http://www.theguardian.com/artanddesign/2013/feb/19/haringey-council-banksy-mural $>$ accessed on $15 / 03 / 2014$
} 